\title{
Optimization of Life Cycle Assessment-Based Eco-efficiency
}

\author{
Kevin Fong-Rey Liu, Jong-Yih Kuo, Yuan-Hua Chang, and Han-Hsi Liang
}

\begin{abstract}
Eco-efficiency (EE) is a concept for quantifying the relationship between economic value creation and environmental impacts. In other words, to be eco-efficient is to add value to goods or services while reducing adverse environmental impacts. In this study, the Eco-indicator 99 was used as a life cycle impact assessment (LCIA) tool to assess environmental impacts. The optimization of $E E$ refers to the maximization of environmental improvement, the minimization of the cost of environmental improvement, or both. Linear programming (LP) was used as an environmental improvement strategy tool to facilitate the optimization of EE. Finally, the optimal strategy for reducing environmental impact in an environmental impact assessment (EIA) was used as a case study.
\end{abstract}

Index Terms-Eco-efficiency (EF), environmental impact assessment (EIA), life cycle impact assessment (LCIA), linear programing (LP).

\section{INTRODUCTION}

The World Business Council for Sustainable Development (WBCSD) has defined eco-efficiency (EE) as follows: "Eco-efficiency is achieved by the delivery of competitively priced goods and services that satisfy human needs and bring quality of life, while progressively reducing ecological impacts and resource intensity throughout the life-cycle to a level at least in line with the Earth's estimated carrying capacity." In short, EE is concerned with creating more value with less impact and can be formulated as a ratio

$$
\text { Eco- efficiency }=\frac{A}{B}
$$

where

$$
\begin{aligned}
A & =\text { product or service value } \\
B & =\text { environmental impact } \\
A & =\text { produce price-production cost-pollution control cost } \\
B & =\text { environmental impact }
\end{aligned}
$$$$
\text { or }
$$$$
\text { or }
$$$$
A=\text { produce price-production cost-pollution }
$$

Manuscript received January 23, 2015; revised March 13, 2015.

K. F. R. Liu is with the Department of Safety, Health and Environmental Engineering, Ming Chi University of Technology, New Taipei City, Taiwan 24301, ROC (e-mail: kevinliu@ mail.mcut.edu.tw).

J. Y. Kuo is with the Department of Safety, Health and Environmental Engineering, Ming Chi University of Technology, New Taipei City, Taiwan. $\mathrm{He}$ is also with the Department of Science and Information Engineering, National Taipei University of Technology, Taipei, Taiwan 10608, ROC (e-mail: jykuo@ntut.edu.tw).

Y. H. Chang is with the Zig Sheng Industrial CO., LTD, Taipei City, Taiwan 10342, ROC (e-mail: old.165@hotmail.com).

H. H. Liang is with the Department of Architecture, National United University, Miaoli, Taiwan 36003, ROC (e-mail: 1hh@nuu.edu.tw). controlcost-cost of environmental improvement

$B=$ environmental impact- environmental improvement

The optimization of eco-efficiency is defined as

$$
\text { Optimization of eco }- \text { efficiency }=\frac{\operatorname{Max} \cdot A}{\operatorname{Min} \cdot B}
$$

where

Max.A = produce price-production cost-pollution controlcost-the minimal cost of environmental improvement

Min. $B=$ environmental impact-the maximally environmental improvement

The denominator, environmental impact, can be evaluated through life cycle impact assessment (LCIA). This study applied the optimization of EE to environmental impact assessment (EIA), as shown in Fig. 1. In an EIA, an EIA committee makes recommendations for environmental improvement and a developer subsequently proposes management plans for achieving the target of environmental improvement. However, the optimal strategy for environmental improvement (pollution reduction) remains unknown. In other words, the key concern for the developer is how to maximize the environmental improvement and minimize the cost of environmental improvement simultaneously.

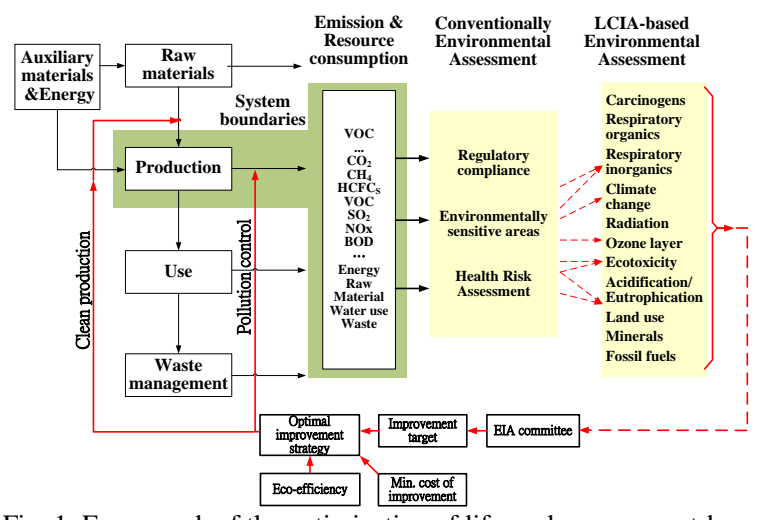

Fig. 1. Framework of the optimization of life cycle assessment-based eco-efficiency in EIA, adapted from [1].

\section{METHODS AND MATERIALS}

\section{A. Evaluating Environmental Impact Using Life Cycle Impact Assessment}

Several studies have reported the feasibility of using LCIA for EIA [1]-[3]. The LCIA phase of an LCA involves the evaluation of potential human health and environmental impacts of the environmental resources and releases identified during the life cycle inventory (LCI). Impact assessment should address ecological and human health effects as well as resource depletion. AnLCIAis used to establish a link between a product or process and its potential 
environmental impacts. A classical LCIA involves selecting the following mandatory elements: impact categories, category indicators and characterization models. At the classification stage, the inventory parameters are categorized and assigned to specific impact categories. In the impact measurement stage, the categorized LCI flows are characterized into common equivalence units, using one of numerous possible LCIA methodologies. These are subsequently summed to provide a total overall impact. The last phase involves "interpretation," which is a systematic technique that identifies, quantifies, checks and evaluates information from the results of the LCI and the LCIA. The results of the inventory analysis and the impact assessment are summarized during the interpretation phase.Eco-indicator 99, which is one of the most widely used impact assessment methods for an LCA was used for this study [4]. Eco-indicator 99 is the successor of Eco-indicator 95, the first endpoint impact assessment method, which allows the environmental load of a product to be expressed in a single score.

\section{B. Optimizing Eco-efficiency by Using Linear Programming}

Linear programming (LP) is a method for achieving the most favorable outcome in a mathematical model whose requirements are represented by linear relationships. LP is aparticular type of mathematical programming (mathematical optimization); it is a technique for the optimization of a linear objective function, subject to linear equality and linear inequality constraints. Its feasible region is a convex polytope, which is a set defined as the intersection of a finite number of half spaces, each of which is defined by a linear inequality. Its objective function is a real-valued affine function defined on this polyhedron. An LP algorithm identifies a point in the polyhedron where this function has the lowest (or highest) value, if such a point exists.

Linear programs are problems that can be expressed in canonical form:

Objective function:

Maximize (or Minimize) $z=c_{1} x_{1}+c_{2} x_{2}+\ldots+c_{n} x_{n}$

Functional or definitional constraints:

Subject to :

$a_{11} x_{1}+a_{12} x_{2} \leq(=, \geqslant) b_{1}$

$a_{21} x_{1}+a_{22} x_{2} \leq(=, \geqslant) b_{2}$

$\cdot \cdot$

$a_{m 1} x_{1}+a_{m 2} x_{2+\ldots} a_{m n} x_{n} \leq(=, \geqslant) \mathrm{b}_{3}$

Non-negativity constraint:

$$
x_{1} \geq 0 ; x_{2} \geq 0
$$

\section{Case Study}

The case study was conducted using a naphtha cracking plant that is located in Yunlin County, Taiwan (Fig. 2). It is in an offshore industrial zone with a total area of 2,603 ha. Currently, as an alternative before expansion (BE), 61 factories have an annual output of 6,221 t. In response to market demand, the company proposed an expansion plan (alternative after expansion; AE) that would increase the number of factories to 77 and increase production to $8,174 \mathrm{t}$ per year, which is an increase of $31.4 \%$ [5].

However, the expansion plan would also increase its emissions of TSP from 3,340 to 4,323 tons per year, $\mathrm{SO}_{2}$ from 16,000 to 19,788 tons per year, $\mathrm{NO}_{2}$ from 19,622 to
23,881 tons per year, VOC from 4,302 to 5,389 tons per year and waste-water from 188,000 to 304,500 tons per day. Its inventory flows, including inputs of water, energy and raw materials, as well as releases to air, land, and water, are detailed in Table I.

TABLE I: INVENTORY DATA FOR CASE STUDY

\begin{tabular}{|c|c|c|c|}
\hline $\begin{array}{c}\text { No. of } \\
\text { Variable }\end{array}$ & Name & Chemical formula & Emission $(\mathrm{Kg})$ \\
\hline $\mathrm{X} 1$ & Acetaldehyde & $\mathrm{C}_{2} \mathrm{H}_{4} \mathrm{O}$ & 79.53 \\
\hline $\mathrm{X} 2$ & Acrolein & $\mathrm{C}_{3} \mathrm{H}_{4} \mathrm{O}$ & 74.65 \\
\hline $\mathrm{X} 3$ & Acrylonitrile & $\mathrm{C}_{3} \mathrm{H}_{3} \mathrm{~N}$ & 841.81 \\
\hline $\mathrm{X} 4$ & Benzene & $\mathrm{C}_{6} \mathrm{H}_{6}$ & 504.62 \\
\hline $\mathrm{X} 5$ & Benzene,1,4-dichloro & $\mathrm{C}_{6} \mathrm{H}_{4} \mathrm{Cl}_{2}$ & 139.76 \\
\hline X6 & Benzene,chloro- & $\mathrm{C}_{6} \mathrm{H}_{5} \mathrm{Cl}$ & 128.36 \\
\hline $\mathrm{X} 7$ & Benzene,ethyl- & $\mathrm{C}_{8} \mathrm{H}_{10}$ & 60.69 \\
\hline $\mathrm{X} 8$ & Butadiene & $\mathrm{C}_{4} \mathrm{H}_{6}$ & 1723.15 \\
\hline $\mathrm{X} 9$ & Carbon dioxide & $\mathrm{CO}_{2}$ & $78,100,000,000$ \\
\hline $\mathrm{X} 10$ & Carbon disulfide & $\mathrm{CS}_{2}$ & 14.49 \\
\hline $\mathrm{X} 11$ & Chloroform & $\mathrm{CHCl}_{3}$ & 1.70 \\
\hline $\mathrm{X} 12$ & Dimethyl formamide & $\mathrm{C}_{3} \mathrm{H}_{7} \mathrm{NO}$ & 1.95 \\
\hline $\mathrm{X} 13$ & Ethane, 1,2-dichloro- & $\mathrm{C}_{2} \mathrm{H}_{4} \mathrm{Cl}_{2}$ & 113.02 \\
\hline $\mathrm{X} 14$ & Ethane,chloro- & $\mathrm{C}_{2} \mathrm{Cl}_{6}$ & 60.93 \\
\hline $\mathrm{X} 15$ & Ethene,chloro- & $\mathrm{CH}_{2} \mathrm{CHCl}$ & 355.79 \\
\hline $\mathrm{X} 16$ & Ethene,trichloro- & $\mathrm{C}_{2} \mathrm{HCl}_{3}$ & 12.49 \\
\hline $\mathrm{X} 17$ & Ethyl acrylate & $\mathrm{C}_{5} \mathrm{H}_{8} \mathrm{O}_{2}$ & 47.67 \\
\hline $\mathrm{X} 18$ & Ethylene oxide & $\mathrm{C}_{2} \mathrm{H}_{4} \mathrm{O}$ & 334.86 \\
\hline X19 & Formaldehyde & $\mathrm{CH}_{2} \mathrm{O}$ & 509.27 \\
\hline $\mathrm{X} 20$ & Hexane & $\mathrm{C}_{6} \mathrm{H}_{14}$ & 925.53 \\
\hline $\mathrm{X} 21$ & $\begin{array}{l}\text { Methane,monochloro-, } \\
\text { R-40 }\end{array}$ & $\mathrm{CH}_{3} \mathrm{Cl}$ & 225.80 \\
\hline $\mathrm{X} 22$ & $\begin{array}{l}\text { Methane, tetrachloro-, } \\
\text { CFC-10 }\end{array}$ & $\mathrm{CCl}_{4}$ & 14.63 \\
\hline $\mathrm{X} 23$ & Methanol & $\mathrm{CH}_{3} \mathrm{OH}$ & 892.97 \\
\hline $\mathrm{X} 24$ & Methyl ethyl ketone & $\mathrm{C}_{4} \mathrm{H}_{8} \mathrm{O}$ & 137.20 \\
\hline $\mathrm{X} 25$ & Methyl methacrylate & $\mathrm{C}_{5} \mathrm{H}_{8} \mathrm{O}_{2}$ & 390.67 \\
\hline $\mathrm{X} 26$ & Naphthalene & $\mathrm{C}_{10} \mathrm{H}_{8}$ & 24.42 \\
\hline $\mathrm{X} 27$ & Nitrogen oxides & $\mathrm{NO}_{\mathrm{X}}$ & $23,880,000$ \\
\hline $\mathrm{X} 28$ & Particulates, & $\mathrm{PM}_{10}$ & $2,160,000$ \\
\hline $\mathrm{X} 29$ & Propylene oxide & $\mathrm{C}_{3} \mathrm{H}_{6} \mathrm{O}$ & 553.46 \\
\hline $\mathrm{X} 30$ & Styrene & $\mathrm{C}_{8} \mathrm{H}_{8}$ & 1585.95 \\
\hline $\mathrm{X} 31$ & Sulfur oxides & $\mathrm{SO}_{\mathrm{X}}$ & $19,790,000$ \\
\hline $\mathrm{X} 32$ & t-Butyl methyl ether & $\mathrm{C}_{5} \mathrm{H}_{12} \mathrm{O}$ & 66.97 \\
\hline X33 & Toluene & $\mathrm{C}_{7} \mathrm{H}_{8}$ & 166.50 \\
\hline X34 & TSP & $\mathrm{PM}_{10}$ & $4,320,000$ \\
\hline X35 & Vinyl acetate & $\mathrm{C}_{4} \mathrm{H}_{6} \mathrm{O}_{2}$ & 106.51 \\
\hline $\mathrm{X} 36$ & $\begin{array}{l}\text { VOC, volatile organic } \\
\text { compounds }\end{array}$ & VOCs & $5,390,000$ \\
\hline $\mathrm{X} 37$ & Xylene & $\mathrm{C}_{8} \mathrm{H}_{10}$ & $1,220.86$ \\
\hline $\mathrm{X} 38$ & Ammonia, as $\mathrm{N}$ & $\mathrm{NH}_{3}, \mathrm{NH}_{4}+$ & 165,600 \\
\hline X39 & Chlorine & $\mathrm{Cl}$ & 10000 \\
\hline $\mathrm{X} 40$ & Chromium & $\mathrm{Cr}$ & 13340 \\
\hline $\mathrm{X} 41$ & $\begin{array}{c}\text { COD,Chemical Oxygen } \\
\text { Demand }\end{array}$ & COD & $3,630,000$ \\
\hline $\mathrm{X} 42$ & Cyanide & $\mathrm{CN}^{-}$ & 1,000 \\
\hline $\mathrm{X} 43$ & Cadmium & $\mathrm{Cd}$ & 1,560 \\
\hline $\mathrm{X} 44$ & Manganese & Mn & 5,560 \\
\hline $\mathrm{X} 45$ & Mercury & $\mathrm{Hg}$ & 110 \\
\hline $\mathrm{X} 46$ & Phosphate & $\mathrm{H}_{3} \mathrm{PO}_{4}$ & 11,110 \\
\hline $\mathrm{X} 47$ & Phosphorus, total & $\mathrm{P}$ & 24,450 \\
\hline $\mathrm{X} 48$ & Selenium & $\mathrm{Se}$ & 16,670 \\
\hline $\mathrm{X} 49$ & Zinc & $\mathrm{Zn}$ & 17,780 \\
\hline $\mathrm{X} 50$ & Arsenic & As & 17,780 \\
\hline $\mathrm{X} 51$ & Lead & $\mathrm{Pb}$ & 21,120 \\
\hline
\end{tabular}




\section{RESULTS}

\section{A. Life Cycle Impact Assessment for Environmental Impact Assessment: Case Study}

The results of using the Eco-indicator 99 for assessing the outcome of the case study are shown in Table II, indicating that the most negative impact on human health is climate change and the most negative impact on the quality of the ecosystem is acidification/ eutrophication.

\begin{tabular}{lccc}
\multicolumn{4}{c}{ TABLE II: ECO-INDICATOR 99 RESULTS FOR CASE STUDY USING [2] } \\
\hline \hline Impact Category (midpoint) & Unit & BE & AE \\
\hline Carcinogens & DALY & $1.030 \mathrm{E}-01$ & $1.309 \mathrm{E}-01$ \\
Respiratory organics & DALY & $2.785 \mathrm{E}+00$ & $3.491 \mathrm{E}+00$ \\
Respiratory inorganics & DALY & $3.255 \mathrm{E}+03$ & $4.018 \mathrm{E}+03$ \\
Climate change & DALY & $1.419 \mathrm{E}+04$ & $1.641 \mathrm{E}+04$ \\
Radiation & DALY & -- & -- \\
Ozone layer & DALY & $1.825 \mathrm{E}-02$ & $2.320 \mathrm{E}-02$ \\
Ecotoxicity & $\mathrm{PDF}^{*} \mathrm{~m}^{2} \mathrm{yr}$ & $6.756 \mathrm{E}+06$ & $1.094 \mathrm{E}+07$ \\
Acidification/ & $\mathrm{PDF}^{*} \mathrm{~m}^{2} \mathrm{yr}$ & $1.287 \mathrm{E}+08$ & $1.570 \mathrm{E}+08$ \\
Eutrophication & $\mathrm{DALY}^{*}$ & $1.745 \mathrm{E}+04$ & $2.043 \mathrm{E}+04$ \\
Human Health & $\mathrm{PDF}^{2} \mathrm{~m}^{2} \mathrm{yr}$ & $1.355 \mathrm{E}+08$ & $1.679 \mathrm{E}+08$ \\
Ecosystem Quality &
\end{tabular}

BE: before the expansion; AE:after the expansion.

\section{B. Scenarios of Possible Improvement}

According to the result of LCIA, not only the amount of pollution emission also the damage to human health and ecosystem quality are provided so that the EIA committee is easier to judge the significance of environmental impact. Subsequently, the committee may ask the developer to commit to improve the environmental impact by reducing emission. The study assumes nine scenarios of possible improvement as follows, that are detailed in Table III.

- Scenario 1: 10\% reduction of the impact on human health

- Scenario 2: 20\% reduction of the impact on human health

- Scenario 3: 50\% reduction of the impact on human health

- Scenario 4: $10 \%$ reduction of the impact on the quality of the ecosystem

- Scenario 5: 20\% reduction of the impact on the quality of the ecosystem

- Scenario 6: $50 \%$ reduction of the impact on the quality of the ecosystem

- Scenario 7: $10 \%$ reduction of the impact on human health and the quality of the ecosystem

- Scenario 8: $20 \%$ reduction of the impact on human health and the quality of the ecosystem

- Scenario 9: 50\% reduction of the impact on human health and the quality of the ecosystem

\section{Cost of Environmental Improvement}

Cost of environmental improvement can be formulated as follows:

Cost of environmental improvement

$=$ cost of pollution reduction

- benefit of pollution reduction

The cost of pollution reduction includes capital, equipment, material, and human resources for the operation and maintenance of pollution control and reduction; the benefit of pollution reduction refers to the savings of emissions tax because of the pollution reduction. The unit costs of environmental improvement for all variables are summarized in Table IV.

TABLE III: NINE SCENARIOS OF ENVIRONMENTAL IMPROVEMENT

\begin{tabular}{|c|c|c|c|c|}
\hline \multirow[b]{2}{*}{ Endpoint } & \multirow[b]{2}{*}{ Impact for $\mathrm{AE}$} & \multicolumn{3}{|c|}{ Scenario } \\
\hline & & No. & $\begin{array}{l}\text { Target of } \\
\text { reduction }\end{array}$ & $\begin{array}{c}\text { Allowance of } \\
\text { emission }\end{array}$ \\
\hline \multirow{3}{*}{$\begin{array}{l}\text { Human } \\
\text { health }\end{array}$} & \multirow{3}{*}{$\begin{array}{l}20,433 \\
(\mathrm{DALY})\end{array}$} & 1 & 2,043 & 18,389 \\
\hline & & 2 & 4,086 & 16,346 \\
\hline & & 3 & 10,216 & 10,216 \\
\hline \multirow{3}{*}{$\begin{array}{l}\text { Ecosystem } \\
\text { quality }\end{array}$} & \multirow{3}{*}{$\begin{array}{l}266,448,452 \\
\left(\mathrm{PDF}^{*} \mathrm{~m}^{2} * \mathrm{yr}\right)\end{array}$} & 4 & $26,644,845$ & $239,803,607$ \\
\hline & & 5 & 53289690 & $213,158,762$ \\
\hline & & 6 & $133,224,226$ & $133,224,226$ \\
\hline \multirow{3}{*}{$\begin{array}{c}\text { (A) } \\
\text { Human health } \\
\text { (B) } \\
\text { Ecosystem } \\
\text { quality }\end{array}$} & \multirow{3}{*}{$\begin{array}{c}\text { (A) } 20,433 \\
\text { (B) } 266,448,452\end{array}$} & 7 & $\begin{array}{c}\text { (A) } 2,043 \\
\text { (B) } 26,644,845\end{array}$ & $\begin{array}{c}\text { (A) } 18,389 \\
\text { (B) } 239,803,607\end{array}$ \\
\hline & & 8 & $\begin{array}{c}\text { (A) } 4,086 \\
\text { (B) } 53,289,690\end{array}$ & $\begin{array}{c}\text { (A) } 16,346 \\
\text { (B) } 213,158,762\end{array}$ \\
\hline & & 9 & $\begin{array}{c}\text { (A) } 10,216 \\
\text { (B) } 133,224,226\end{array}$ & $\begin{array}{c}\text { (A) } 10,216 \\
\text { (B) } 133,224,226\end{array}$ \\
\hline
\end{tabular}

\section{Optimizing Eco-efficiency}

The optimization of EE is performed using LP, which comprises the following four parts.

- Objective function: Minimize cost of environmental cost.

- Constraint 1: Environmental improvement of impact on human health is greater than or equal to the target reduction.

- Constraint 2: Environmental improvement of impact on the quality of the ecosystem is greater than or equal to the target reduction.

- Constraint 3: Emissions reduction of each variable is less than or equal to its emissions but not negative.

\begin{tabular}{cc} 
TABLE IV: UNIT COST OF ENVIRONMENTAL IMPROVEMENT \\
\hline \hline No of variable & $\begin{array}{c}\text { Unit cost of pollution reduction } \\
\text { (NTD/Kg) }\end{array}$ \\
\hline X1-X8 & 30.6 \\
X9 & 615.72 \\
X10-X26 & 30.6 \\
X27 & 51.30 \\
X28-X30 & 30.6 \\
X31 & 73.22 \\
X32-X33 & 30.6 \\
X34 & 25.55 \\
X35 & 30.6 \\
X36 & 5.6 \\
X37 & 30.6 \\
X38 & 31,600 \\
X39 & 3,948 \\
X40 & 31600 \\
X41 & 79,000 \\
X42 & 6,320 \\
X43 & 158,000 \\
X44 & 249.76 \\
X45 & 158,000 \\
X46 & 15,800 \\
X47 & 63,200 \\
X48 & 12,640 \\
X49 & 6,320 \\
X50 & 3,160 \\
X51 & 6,320 \\
\hline & \\
\hline \hline & \\
\hline &
\end{tabular}


Scenarios 1, 2 and 3 are the environmental improvement of impact on human health with targets of $10 \%, 20 \%$ and $50 \%$ reduction, respectively; their optimal reductions are shown in Table V - Table VIII, respectively. Avariable does not reduce its emission if it is not listed in these tables.

TABLE V: ENVIRONMENTAL IMPROVEMENT FOR SCENARIO 1

\begin{tabular}{lccc}
\hline \hline No. & Emission $(\mathrm{Kg})$ & Reduction $(\mathrm{Kg})$ & Reduction $(\%)$ \\
\hline X18 & 334.86 & 334.86 & 100 \\
X22 & 14.63 & 14.63 & 100 \\
X27 & $23,880,000$ & 13840,900 & 57.96 \\
X28 & $2,160,000$ & $2,160,000$ & 100 \\
\hline \hline
\end{tabular}

TABLE VI: ENVIRONMENTAL IMPROVEMENT FOR SCENARIO 2 (X1-X23)

\begin{tabular}{lccc}
\hline \hline No. & Emission $(\mathrm{Kg})$ & Reduction $(\mathrm{Kg})$ & Reduction $(\%)$ \\
\hline X1 & 79.53 & 79.53 & 100 \\
X2 & 74.65 & 74.65 & 100 \\
X3 & 841.81 & 841.81 & 100 \\
X4 & 504.62 & 504.62 & 100 \\
X7 & 60.69 & 60.69 & 100 \\
X8 & 1723.15 & 1723.15 & 100 \\
X9 & $78,148,750,000$ & $308,291,300$ & 0.39 \\
X11 & 1.7 & 1.70 & 100 \\
X13 & 113.02 & 113.02 & 100 \\
X15 & 355.79 & 355.79 & 100 \\
X16 & 12.49 & 12.49 & 100 \\
X18 & 334.86 & 334.86 & 100 \\
X19 & 509.27 & 509.27 & 100 \\
X20 & 925.53 & 925.53 & 100 \\
X21 & 225.8 & 225.80 & 100 \\
X22 & 14.63 & 14.63 & 100 \\
X23 & 892.97 & 892.97 & 100 \\
\hline \hline
\end{tabular}

TABLE VII: ENVIRONMENTAL IMPROVEMENT FOR SCENARIO 2 (X24-37))

\begin{tabular}{lccc}
\hline \hline No. & Emission $(\mathrm{Kg})$ & Reduction $(\mathrm{Kg})$ & Reduction $(\%)$ \\
\hline X24 & 137.2 & 137.20 & 100 \\
X27 & $23,880,000$ & $23,880,000$ & 100 \\
X28 & $2,160,000$ & $2,160,000$ & 100 \\
X29 & 553.46 & 553.46 & 100 \\
X30 & $1,585.95$ & 1585.95 & 100 \\
X31 & $19,790,000$ & $19,790,000$ & 100 \\
X32 & 66.97 & 66.97 & 100 \\
X33 & 166.5 & 166.50 & 100 \\
X36 & $5,390,000$ & $5,390,000$ & 100 \\
X37 & $1,220.86$ & $1,220.86$ & 100 \\
\hline \hline
\end{tabular}

TABLE VIII: ENVIRONMENTAL IMPROVEMENT FOR SCENARIO 3

\begin{tabular}{lccc}
\hline \hline No. & Emission $(\mathrm{Kg})$ & Reduction $(\mathrm{Kg})$ & Reduction $(\%)$ \\
\hline X1 & 79.53 & 79.53 & 100 \\
X2 & 74.65 & 74.65 & 100 \\
X3 & 841.81 & 841.81 & 100 \\
X4 & 504.62 & 504.62 & 100 \\
X7 & 60.69 & 60.69 & 100 \\
X8 & $1,723.15$ & 1723.15 & 100 \\
X9 & $78,148,750,000$ & $29,498,460,000$ & 37.75 \\
X11 & 1.70 & 1.70 & 100 \\
X13 & 113.02 & 113.02 & 100 \\
X15 & 355.79 & 355.79 & 100 \\
X16 & 12.49 & 12.49 & 100 \\
X18 & 334.86 & 334.86 & 100 \\
X19 & 509.27 & 509.27 & 100 \\
X20 & 925.53 & 925.53 & 100 \\
X21 & 225.80 & 225.80 & 100 \\
X22 & 14.63 & 14.63 & 100 \\
\hline
\end{tabular}

\begin{tabular}{lccl} 
X23 & 892.97 & 892.97 & 100 \\
X24 & 137.2 & 137.2 & 100 \\
X27 & $23,880,000$ & $23,880,000$ & 100 \\
X28 & $2,160,000$ & $2,160,000$ & 100 \\
X29 & 553.46 & 553.46 & 100 \\
X30 & 1585.95 & 1585.95 & 100 \\
X31 & $19,790,000$ & $19,790,000$ & 100 \\
X32 & 66.97 & 66.97 & 100 \\
X33 & 166.5 & 166.5 & 100 \\
X36 & $5,390,000$ & $5,390,000$ & 100 \\
X37 & $1,220.86$ & $1,220.86$ & 100 \\
\hline \hline
\end{tabular}

\section{DISCUSSION}

TABLE IX: IMPROVEMENT EFFICIENCYOF VARIABLES

\begin{tabular}{|c|c|c|c|c|}
\hline No. & $\begin{array}{l}\text { Characterization } \\
\text { factor } \\
\text { (DALY/Kg) }\end{array}$ & $\begin{array}{l}\text { Unit cost of } \\
\text { pollution reduction } \\
(\mathrm{NTD} / \mathrm{Kg})\end{array}$ & $\begin{array}{c}\text { Improvement } \\
\text { efficiency } \\
\text { (DALY/NTD) }\end{array}$ & Rank \\
\hline $\mathrm{X} 1$ & $1.58 \mathrm{E}-06$ & 30.607 & $5.15 \mathrm{E}-08$ & 16 \\
\hline $\mathrm{X} 2$ & $1.70 \mathrm{E}-06$ & 30.607 & $5.55 \mathrm{E}-08$ & 15 \\
\hline X3 & $1.69 \mathrm{E}-05$ & 30.607 & $5.52 \mathrm{E}-07$ & 10 \\
\hline $\mathrm{X} 4$ & $2.97 \mathrm{E}-06$ & 30.607 & $9.70 \mathrm{E}-08$ & 12 \\
\hline X5 & 0 & 30.607 & 0 & 28 \\
\hline X6 & 0 & 30.607 & 0 & 28 \\
\hline $\mathrm{X} 7$ & $1.53 \mathrm{E}-06$ & 30.607 & $5.00 \mathrm{E}-08$ & 17 \\
\hline $\mathrm{X} 8$ & $1.77 \mathrm{E}-05$ & 30.607 & 5.77E-07 & 9 \\
\hline X9 & $2.10 \mathrm{E}-07$ & 615.715 & $3.41 \mathrm{E}-10$ & 27 \\
\hline X10 & 0 & 30.607 & 0 & 28 \\
\hline $\mathrm{X} 11$ & $2.72 \mathrm{E}-05$ & 30.607 & 8.88E-07 & 7 \\
\hline $\mathrm{X} 12$ & 0 & 30.607 & 0 & 28 \\
\hline $\mathrm{X} 13$ & $3.02 \mathrm{E}-05$ & 30.607 & $9.85 \mathrm{E}-07$ & 6 \\
\hline $\mathrm{X} 14$ & 0 & 30.607 & 0 & 28 \\
\hline $\mathrm{X} 15$ & $2.09 \mathrm{E}-07$ & 30.607 & $6.83 \mathrm{E}-09$ & 25 \\
\hline $\mathrm{X} 16$ & 7.78E-07 & 30.607 & $2.54 \mathrm{E}-08$ & 21 \\
\hline $\mathrm{X} 17$ & 0 & 30.607 & 0 & 28 \\
\hline X18 & $1.83 \mathrm{E}-04$ & 30.607 & $5.98 \mathrm{E}-06$ & 3 \\
\hline X19 & $2.10 \mathrm{E}-06$ & 30.607 & $6.86 \mathrm{E}-08$ & 14 \\
\hline $\mathrm{X} 20$ & $1.02 \mathrm{E}-06$ & 30.607 & 3.33E-08 & 19 \\
\hline $\mathrm{X} 21$ & $3.94 \mathrm{E}-05$ & 30.607 & $1.29 \mathrm{E}-06$ & 5 \\
\hline $\mathrm{X} 22$ & $1.84 \mathrm{E}-03$ & 30.607 & $6.01 \mathrm{E}-05$ & 1 \\
\hline $\mathrm{X} 23$ & 2.81E-07 & 30.607 & $9.18 \mathrm{E}-09$ & 24 \\
\hline $\mathrm{X} 24$ & $8.09 \mathrm{E}-07$ & 30.607 & $2.64 \mathrm{E}-08$ & 20 \\
\hline $\mathrm{X} 25$ & 0 & 30.607 & 0 & 28 \\
\hline $\mathrm{X} 26$ & 0 & 30.607 & 0 & 28 \\
\hline $\mathrm{X} 27$ & 8.91E-05 & 51.3064 & $1.74 \mathrm{E}-06$ & 4 \\
\hline $\mathrm{X} 28$ & $3.75 \mathrm{E}-04$ & 30.607 & $1.23 \mathrm{E}-05$ & 2 \\
\hline $\mathrm{X} 29$ & $1.17 \mathrm{E}-05$ & 30.607 & $3.82 \mathrm{E}-07$ & 11 \\
\hline $\mathrm{X} 30$ & $2.44 \mathrm{E}-08$ & 30.607 & 7.97E-10 & 26 \\
\hline X31 & $5.46 \mathrm{E}-05$ & 73.2261 & 7.46E-07 & 8 \\
\hline $\mathrm{X} 32$ & 3.32E-07 & 30.607 & $1.08 \mathrm{E}-08$ & 23 \\
\hline X33 & $1.36 \mathrm{E}-06$ & 30.607 & 4.44E-08 & 18 \\
\hline $\mathrm{X} 34$ & 0 & 25.5595 & 0 & 28 \\
\hline X35 & 0 & 30.607 & 0 & 28 \\
\hline $\mathrm{X} 36$ & $6.46 \mathrm{E}-07$ & 30.607 & $2.11 \mathrm{E}-08$ & 22 \\
\hline $\mathrm{X} 37$ & $2.21 \mathrm{E}-06$ & 30.607 & 7.22E-08 & 13 \\
\hline X38 & 0 & 3948 & 0 & 28 \\
\hline X39 & 0 & 79000 & 0 & 28 \\
\hline $\mathrm{X} 40$ & 0 & 6320 & 0 & 28 \\
\hline $\mathrm{X} 41$ & 0 & 249.76 & 0 & 28 \\
\hline $\mathrm{X} 42$ & 0 & 31600 & 0 & 28 \\
\hline $\mathrm{X} 43$ & 0 & 31600 & 0 & 28 \\
\hline
\end{tabular}




\begin{tabular}{llcll} 
X44 & 0 & 15800 & 0 & 28 \\
X45 & 0 & 158000 & 0 & 28 \\
X46 & 0 & 63200 & 0 & 28 \\
X47 & 0 & 12640 & 0 & 28 \\
X48 & 0 & 158000 & 0 & 28 \\
X49 & 0 & 6320 & 0 & 28 \\
X50 & 0 & 6320 & 0 & 28 \\
X51 & 0 & 3160 & 0 & 28 \\
\hline \hline
\end{tabular}

The optimal strategies of reducing emission are summarized in the following guidelines.

- The selected variables are all basic solutions.The variables X18, X22, X27 and X28 in Scenario 1 are basic solutions because their reduced costs are zero, as shown in Table $\mathrm{V}$.

- The variables are reduced by the ranks of theirimprovement efficiencies. The improvement efficiency of a variable is defined as follows:

Improvement efficiency of a variable(DALY/NTD or $\left.\mathrm{PDF}^{*} \mathrm{~m}^{\wedge} 2 * \mathrm{yr} / \mathrm{NTD}\right)$

$=\frac{\text { Charactorization factor }\left(D A L Y / K g \text { or } P D F * m^{\wedge} 2 * y r / K g\right.}{\text { Unit cost of pollution reduction }(N T D / K g)}$

For example, the characterization factor of variable $\mathrm{X} 1$ (acetaldehyde) is $1.58 \mathrm{E}-06$ (DALY/Kg) and its unit cost of pollution reduction is 30.607 ( $\mathrm{Kg} / \mathrm{NTD})$; therefore, its improvement efficiency is 5.15E-08 (DALY/NTD). Thus, the improvement efficiencies of all variables are derived, as shown in Table IX.

\section{CONCLUSION}

In this study, the optimization of LCIA-based EE was most favorably applied in EIA. The EIA committee recommends environmental improvements and asks developers to commit by providing targets for pollution reductions. For developers, the optimal strategy is to achieve the targets at minimal costs, which refer to EE. The findings of this study reveal that targets are approached by the ranks of improvement efficiency of variables. Future studies should further investigate the improvement efficiency when simultaneously considering human health and the quality of the ecosystem. Placing improvement on impact categories (midpoints) rather than on endpoints requires more effort. Finally, how to develop a trade-off strategy of environmental improvement is a crucial consideration when targets are multiple and conflict.

\section{ACKNOWLEDGMENT}

The authors would like to thank the Ministry of Science and Technology of the Republic of China (Taiwan) for financially supporting this research under Contract MOST 103-2221-E-131-001-MY2.

\section{REFERENCES}

[1] A. Tukker, "Life cycle assessment as a tool in environmental impact assessment," Environmental Impact Assessment Review, vol. 20, no. 4, pp. 435-456, 2000

[2] K. F.-R. Liu, C.-Y. Ko, C. Fan, and C.-W. Chen, "Incorporating the LCIA concept into fuzzy risk assessment as a tool for environmental impact assessment," Stochastic Environmental Research and Risk Assessment, vol. 27, no. 4, pp. 849-866, 2013.

[3] K. F.-R. Liu, M.-J. Hung, P.-C. Yeh, and J.-Y. Kuo, "GIS-based regionalization of LCA," Journal of Geoscience and Environment Protection, vol. 2, no. 2, pp. 1-8, 2014.

[4] M. J. Goedkoop and R. Spriensma, The Eco-indicator $99-A$ Damage-oriented Method for Life Cycle Impact Assessment. Methodology Report, second ed., 17-4-2000. Pre' Consultants, B. V. Amersfoort, The Netherlands, 2000.

[5] K. F.-R. Liu, S.-Y. Chiu, P.-C. Yeh, and J.-Y. Kuo, "Case study of using life cycle impact assessment in environmental impact assessment," International Journal of Environmental Science and Development, vol. 4, no. 6, pp. 652-657, 2013.

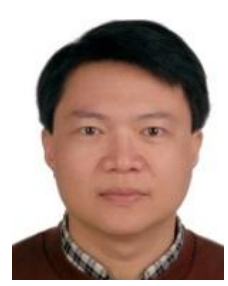

Kevin Liu received the Ph.D. degree in 1998, in civil engineering from National Central University, Taiwan. Currently, he is a professor in the Department of Safety, Health and Environmental Engineering, Ming Chi University of Technology, Taiwan. His research interest is the use of decision analysis and artificial intelligence techniques to environmental management issues.

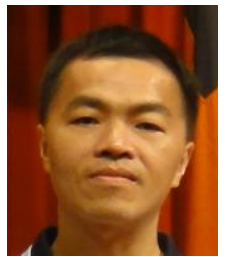

Jong-Yih Kuo received the Ph.D. degree in 1998, in computer science and information engineering from National Central University, Taiwan. Currently, he is an associate professor in the Department of Computer Science and Information Engineering, National Taipei University of Technology, Taiwan. His research interests are in agent-base software engineering, intelligent agent system and fuzzy theory.

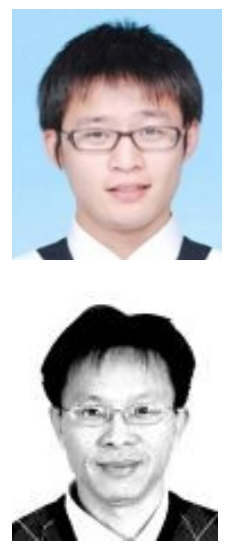

Yuan-Hua Chang received the master degree in 2013 , in the Department of Safety, Health and Environmental Engineering, Ming Chi University of Technology, Taiwan. He currently works for the Zig Sheng Industrial CO., LTD.

Han-Hsi Liang received the Ph.D. degree in civil engineering from National Central University, Taiwan, in 1997. He is currently an associate professor with the Department of Architecture, National United University, Taiwan, R.O.C. His research interests include decision making, green building, building material and construction management. 